NBER WORKING PAPER SERIES

\title{
THE DEVELOPED WORLD'S DEMOGRAPHIC TRANSITION - THE ROLES OF CAPITAL FLOWS, IMMIGRATION, AND POLICY
}

\author{
Hans Fehr \\ Sabine Jokisch \\ Laurence Kotlikoff \\ Working Paper 10096 \\ http://www.nber.org/papers/w10096
}

\author{
NATIONAL BUREAU OF ECONOMIC RESEARCH \\ 1050 Massachusetts Avenue \\ Cambridge, MA 02138 \\ November 2003
}

Research support by the Deutsche Forschungsgemeinschaft (grant: FE377/4-1), the Universitätsbund Würzburg, the National Institute of Aging, the Smith Richardson Foundation, and Boston University is gratefully acknowledged. We would also like to thank Charles Horioka, Bernd Raffelhüschen and Reinhold Schnabel for providing data on wealth, population and health care. The views expressed herein are those of the authors and not necessarily those of the National Bureau of Economic Research.

(C)2003 by Hans Fehr, Sabine Jokisch, and Laurence Kotlikoff. All rights reserved. Short sections of text, not to exceed two paragraphs, may be quoted without explicit permission provided that full credit, including (C) notice, is given to the source. 
The Developed World's Demographic Transition -

The Roles of Capital Flows, Immigration, and Policy

Hans Fehr, Sabine Jokisch, and Laurence Kotlikoff

NBER Working Paper No. 10096

November 2003

JEL No. H0

\begin{abstract}
$\underline{\text { ABSTRACT }}$
The developed word stands at the fore of a phenomenal demographic transition. Over the next 30 years the number of elderly in the U.S., the EU, and Japan will more than double. At the same time, the number of workers available to pay the elderly their government-guaranteed pension and health care benefits will rise by less than 10 percent. The fiscal implications of these two demographic trends are alarming. Paying promised benefits will, it appears, require a doubling or more of payroll tax rates. This paper asks if there is a silver lining in this dark cloud hanging over the developed world. Specifically, can the developed economies hope to be bailed out by either macroeconomic feedback effects of by increased migration?
\end{abstract}

To address these questions, this paper develops and simulates a dynamic, intergeneration, and interregional demographic life-cycle model. The model has three regions - the U.S., the EU, and Japan - which exchange goods and capital. The model features immigration, age-specific fertility, life span extension, life span uncertainty, bequests arising from incomplete annuitization, and intracohort heterogeneity.

Other things equal, one would expect the aging of the developed economies to increase capital per worker as the number of suppliers of capital (the old) rises relative to the number of suppliers of labor (the young). But given the need to pay the elderly their benefits, other things are far from equal. According to our simulations, the tax hikes needed to finance benefits along the demographic transition path generate a major capital shortage that lowers real wages by 19 percent and raises real interest rates by over 400 basis points. Hence, far from mitigating the developed world's fiscal problems, macroeconomic feedback effects make matters significantly worse.

The simulations also show that increased immigration does very little to mitigate the fiscal stresses facing the developed world. On the other hand, there are policies that can materially improve the developed world's long-term prospects. The one examined here is closing down, at the margin, existing government pension systems and using consumption taxes to pay off those program's accrued liabilities. This policy could be coupled with the establishment of a fully funded mandatory individual saving system. According to our simulations, this policy would impose modest welfare losses on current generations, but generate enormous welfare gains for future generations. Future Europeans and Japanese benefit the most. Their net wages almost triple, and their welfare levels double compared with the no-reform scenario.

Hans Fehr

University of Wuerzburg

Sabine Jokisch

University of Wuerzburg
Laurence Kotlikoff

Department of Economics

Boston University

270 Bay State Road

Boston, MA 02215

and NBER

kotlikof@bu.edu 


\section{Introduction}

The developed world is about to experience an unprecedented demographic change. In virtually all OECD countries, people are getting older - a lot older. And everywhere the reason is the same - a dramatic baby boom followed by an equally dramatic baby bust, all accompanied by a remarkable increase in life expectancy. These demographic events are slated, over the next four decades, to more than double the dependency ratio - the ratio of retirees to workers. Since the elderly depend on the young to pay their government-guaranteed pension and health-care benefits, the extraordinary aging of developed societies augers a fiscal crisis of the first order. Indeed, payroll taxes, which are already extremely high in most developed countries, will, it seems, need to more than double to pay promised benefits. The alternative to such massive tax hikes is, of course, major benefit cuts. Both policies are, of course, anathema to politicians. So whatever fiscal adjustments are eventually made will likely be delayed to the last minute, making those adjustments that much more painful.

This bleak assessment of developed economies' future fiscal prospects ignores two factors that are increasingly raised as possible sources of economic salvation. The first is the macroeconomic impact of aging, specifically the potential for capital deepening. The second is the option to dramatically increase immigration.

Were aging to raise the stock of capital compared to the supply of labor, real wages would increase and, thereby, expand the taxable wage base. This would limit the need for higher payroll taxes. The prospect for such capital deepening arises from the fact that the elderly are the primary owners and, thus, the main suppliers of capital, while the young are the main suppliers of labor. All else equal, more oldsters relative to youngsters means a greater supply of capital relative to labor.

Unfortunately, all else will not be equal in either the short or long runs. In particular, if benefits are paid as promised, the requisite tax increases will undermine capital formation as workers' wages, some of which would otherwise be saved, are taken from them and handed over to the elderly to finance immediate consumption. 
Thus, the net impact on capital intensity, real wages, and the payroll tax base of aging cannot be determined a priori and must be simulated within a fully articulated and carefully calibrated model. The same is true when it comes to understanding the fiscal implications of increased immigration. Importing additional workers will certainly raise the payroll tax base. But more immigrants also mean more expenditures on education, public safety, water and sewer systems, and a host of other public goods. More immigrants also mean more government pension and health care spending since immigrants also accrue rights to such benefits. Moreover, most developed countries provide benefits to the elderly on a progressive basis. And since immigrants are disproportionately low-wage earners, they typically receive more benefits per dollar of tax payments than do native worker. Hence, the precise benefit to the developed world's future fiscal finances and economies from immigration also requires detailed computation rather than simply theoretical contemplation.

Calculations of the type to which we are referring occupy a large and growing literature. Many of these studies are based on the overlapping generation model (OLG) developed by Auerbach and Kotlikoff (1987). Typically, such studies focus on a single, closed economy. Auerbach, et. al. (1989) is an exception. It models four OECD countries, but treats each as a small open economy. This treatment rules out either crowding out or crowding in of capital per worker since capital flows in or out of small open economies until the return from capital equals the level set from abroad. The one exception to this statement arises in the case of differential changes in corporate tax rates at home and abroad.

More recent contributions have begun to explore the effects of ageing within general equilibrium, open-economy models. The French INGENUE (2002) team has developed an OLG model that divides the world into six large regions, three developed and three developing areas, each of which has quite different demographics. They find a small negative impact of ageing on the world interest rate. Boersch-Supan, et. al. (2002) have set up a three-region OLG model, featuring Germany, Europe, and the rest of the OECD, in order to examine the international ramifications of alternative German pension reforms. They find very little change in capital-labor ratios in their open economy simulations. 
In this paper, we also specify and simulate a large open economy model. Our model features three developed regions - the US, the EU, and Japan. For each region we incorporate a detailed set of fiscal institutions. We also include capital adjustment costs, immigration, agespecific fertility rates, life span extension, life span uncertainty, bequests arising from incomplete annuitization, and intra-cohort heterogeneity. Many of these features have been included in other studies. But this appears to be the first study to include all of these elements in the same framework.

Like other dynamic life-cycle models featuring fertility, our model features monozygotic reproduction. But to achieve a realistic pattern of births by age, we follow Kotlikoff, et. al. (2001) in assuming that agents in their child-bearing years give birth each year to fractions of children. By specifying how age-specific fertility rates change through time, we can line up our model's age-specific population counts of children and workers fairly closely with those forecast for the three regions. To do the same with respect to the population of the elderly, we assume that agents die with realistic mortality probabilities starting at age 68 .

Agents fully appreciate their longevity uncertainty and maximize, at each point in time, their expected remaining lifetime utilities. The inclusion of lifespan uncertainty provides three advantages in addition to getting agents to die on time. First, it permits a more realistic modelling of bequests and inheritances. The standard method for including bequests in dynamic simulation models is to posit that agents derive utility from leaving bequests. Here we make no such assumption. Instead, we generate bequests by assuming, realistically, that agents fail to annuitize their assets in old age. Hence, when they die they leave undesired bequests to their children. This treatment of bequests finds support in a recent study by Gokhale, Kotlikoff, Sefton, and Weale (2001), which shows that a model of undesired bequests and earnings inequality can closely replicate the U.S. distribution of wealth, including its Gini coefficient and top tail.

The second advantage involves the age-distributions of bequests and inheritances. With the exception of De Nardi, İmrohoroğlu, and Sargent (1999), previous modelling of bequests in dynamic models have assumed that all agents die at a given age and all agents inherit at a 
given age. In our model, agents die at different ages, based on realistic mortality probabilities, and their heirs inherit at different ages.

The third advantage of incorporating uninsurable lifespan uncertainty is that it leads to a gradual decline in consumption in old age. This is a feature of actual longitudinal ageconsumption profiles. The other key feature of actual consumption profiles is the hump that appears during child-rearing years. Our model delivers this hump as well since agents in our model care about their children's utility when they are young and spend more on consumption when their kids are at home.

A final feature of our framework worth flagging at the outset is the inclusion of capital adjustment costs. As is well known, these costs can drive temporary wedges between the marginal products of capital in different regions and lead the market values of capital assets to temporarily differ from their replacement costs. The inclusion of adjustment costs generates what amounts to regional stock markets and permits us to explore how stock values respond to aging as well as policy responses to aging.

Our paper begins by describing the demographic transition in the three regions and simulating closed-economy baseline transition paths. We then show how the three closed economies response to increased immigration and pension privatization. These results provide useful reference points for our subsequent presentation of the open-economy baseline and policy reforms.

Our baseline simulations keep immigration at current levels, incorporate projected increases over time in life expectancy, and maintain current pay-as-you-go finance of government retirement and old-age health care benefits. With these baseline results as a reference point, we consider the macroeconomic and welfare effects of two alternative policy reforms - a doubling of immigration and the privatization of government pension systems, where the payoff of the accrued liabilities of the existing systems is financed by a special consumption tax.

\section{Modelling the World Economy}

This section discusses the demographic and economic structure of our model. A more detailed description of population projections, data sources, models assumptions, and calibration 
is provided in Fehr, et. al. (2003). To limit notation we suppress regional indices to the extent possible.

\section{Demographic Structure}

Each region is populated by households who live up to a maximum age of 90 . Consequently, we distinguish up to 91 generations within each period $t$. The individual life-cycle of a representative agent is described in Figure 1. Between ages 0 and 20 our agents are children, who earn no money and are supported by their parents. At age 21 our agents leave their parents and start working. Between ages 23 and 45 our agents give birth to fractions of children at the beginning of each period, i.e. the first (fraction of) children are born when the parents are 23 and the last are born when they are age 45. An agent's first-born children (fractions of children) leave home when the parents are age 43, while the last-born leave their parents when they are age 66 . Our agents die between ages 68 and 90 . The probability of death is one at age 91. Children always outlive their parents, meaning that parents always outlive grandparents. To see this note that if a parent reaches age 90 , his or her oldest children will be 67 . These are children who were born when the parent was age 23 .

In each year, new immigrants arrive with their children. After crossing the border, immigrants automatically become natives in an economic sense, i.e. they have identical wealth endowments (which we assume they bring with them) to natives in the same age-cohort and earnings class. They also have the same preferences and fractions of children of different ages as natives in their age-cohort and earnings class.

The starting point for specifying the current and future demographic structure of each region are the year-2000 existing age-specific population $[\bar{N}(a, 2000)]$ and age-specific netimmigration $[\overline{N M}(a, 2000)]$ structures. To determine the numbers and ages of children alive in 2000, we used data on birth rates prior to 2000. To determine the evolution over time of population in each region, we applied region- and age-specific mortality $[d(a, i)]$ and birth rates to the cohorts alive in year 2000 as well as to their children as they reach their ages of fertility and mortality. 
In constructing existing as well as future age-population counts, we have to link each initial cohort between the ages of 1 and 68 to those of their parents who are still alive. The reason is that children receive bequests from their parents and the levels and timing of these inheritances depend on the ages of their parents. This linkage is achieved by applying past relative fertility rates to each cohort of age 1 to 68 in year 2000. If, for example, 15 percent of the parents of newborns in 1980 were 25 years old, then 15 percent of the 20-year-olds in year 2000 are assigned to parents age 45. In addition, each cohort is split into three income classes $k$. Specifically, we assume that 30 percent of each cohort belong to the lowest income class, 10 percent to the top income class, and the remaining 60 percent to the middle income class. Formally, we denote the final population vector for year 2000 as $N(a, 2000, s, k)$ where $a=1, \ldots, 90, s=23, \ldots, 45, k=1,2,3$. The term $s$ references the age of the parent at the time of birth of agents age $a$ in 2000 .

We use the population age structure in year 2000 as well as projected future fertility, mortality, and net-immigration rates to compute the population vector $N(a, t, s, k)$ for the years $t$ between 2001 and 2050. After year 2050, mortality rates and net immigration rates are kept constant and fertility rates are endogenously adjusted in order to achieve a stable population age structure in the future. In the baseline path, we assume annual net-immigration of 1 million per year in the US, 450,000 in the EU, and 54,000 in Japan. Figures 2 and 3 report our projected life expectancy and the fertility rates in the three regions between 2000 and 2100 .

Our exogenous predictions of the current and future mortality and fertility rates follow the medium variant of United Nations Population Division (UNPD) (2003). While mortality is decreasing in all three regions until 2050, the Japanese have a significantly higher life expectancy than Americans or E.U. citizens. Since people don't die in the model before age 68, life expectancies at birth are higher than predicted. However, in year 2000 the model's life expectancies conditional on reaching age 60 in our model are close to those reported by the UNDP (2003).

Total fertility rates are currently much higher in the US than in Japan or in Europe. While the Japanese and European rates are predicted to increase until 2050, the U.S. rates 
remains roughly constant. The drop in the U.S. fertility rate staring in 2050 reflects our assumption of zero population growth in all three regions after that year. In the U.S. the high rate of immigration requires a reduction in the fertility rate after 2050 to achieve zero population growth. Figures 4 and 5 report the resulting change in the total population and the dependency ratio.

Due to its relatively high fertility and immigration rate, the U.S. population increases from 275 million in 2000 to 505 million in 2100. In Europe, the total population falls over the century from 375 to 340 million. And in Japan, the population falls from 126 million to 83 million! As one would expect, dependency ratios are increasing in all three regions up to 2050. However, the three regions experience important differences in their population aging. First, the increase in the dependency ratio is much greater in Japan and Europe than in the US. Second, dependency ratios fall in Europe and Japan after peaking in year 2050, while they remain roughly stable after 2030 in the US.

As agents age, their household compositions change as they have more children and as older children reach adulthood. These changes materially alter consumption and saving decisions. Given age $a$ of an agent in income class $k$ in a specific year $t$, the number of her children is calculated as

$$
K I D(a, t, k)=\sum_{j=u}^{m} \frac{N(j, t, a-j, k)}{\sum_{s=23}^{45} N(a, t, s, k)} \quad 23 \leq a \leq 65, k=1,2,3,
$$

where $u=\max (0 ; a-45)$ and $m=\min (20, a-23)$. Recall that agents younger than 23 have no children and those over 65 have only adult children, i.e. $K I D(a, t, k)=0$ for $0 \leq a \leq 22$ and $66 \leq a \leq 90$. Agents in between these ages have children. Take, for example, a 30 year-old agent. Such an agent has children who were born in the years $(a-j)$ in the years since he was 23. In year $t$, these children are between age $0 \leq j \leq 7$. The kids function (1) sums the total number of kids of the respective parent-income class generation and divides it by the total number of parents of age $a$ in year $t$ who belong to income class $k$. The KID-function (1) takes into account that the family's age structure will change over time due to changing fertility. Our approach also permits the distribution of births by the age of parents to change over time. This 
is an improvement compared to Kotlikoff, et. al. (2001).

\section{Preferences and Household Budget Constraints}

As previously mentioned, we do not distinguish between natives and immigrants in the model once the immigrants have joined their domestic earnings- and age-specific cohorts. The model's preference structure is represented by a time-separable, nested CES utility function. Remaining lifetime utility $U(j, t, s, k)$ of a generation of age $j$ at time $t$ whose parents were age $s$ at time of birth and who belongs to income class $k$ takes the form

$$
U(j, t, s, k)=V(j, t, s, k)+H(j, t, s, k)
$$

where $V(j, t, s, k)$ records the agent's utility from her/his own goods and leisure consumption and $H(j, t, s, k)$ denotes the agent's utility from the consumption of her/his children. The two sub-utility functions are defined as follows:

$$
\begin{aligned}
V(j, t, s, k) & =\frac{1}{1-\frac{1}{\gamma}} \sum_{a=j}^{90}\left(\frac{1}{1+\theta}\right)^{a-j} P(a, i)\left[c(a, i, s, k)^{1-\frac{1}{\rho}}+\alpha \ell(a, i, s, k)^{1-\frac{1}{\rho}}\right]^{\frac{1-\frac{1}{\gamma}}{1-\frac{1}{\rho}}} \\
H(j, t, s, k) & =\frac{1}{1-\frac{1}{\gamma}} \sum_{a=j}^{90}\left(\frac{1}{1+\theta}\right)^{a-j} P(a, i) K I D(a, i, k) c_{K}(a, i, s, k)^{1-\frac{1}{\gamma}},
\end{aligned}
$$

where $c(a, i, s, k)$ and $\ell(a, i, s, k)$ denote consumption and leisure, respectively and $i$ is defined as $i=t+a-j$. The children's consumption of income class $k$ parents who are age $a$ at period $i$ and whose parents were age $s$ at the time of their birth is defined as $c_{K}(a, i, s, k)$. Note that the number of children is independent of the grandparents' age at the time of the birth of the parents.

Since lifespan is uncertain, the utility of consumption in future periods is weighted with the survival probability of reaching age $a$ in year $i$

$$
P(a, i)=\prod_{u=j}^{a}[1-d(u, u-a+i)]
$$

which are determined by multiplying the conditional survival probabilities from year $t$ (when the agents age is $j$ ) up to year $i$. Note that $\mathrm{d}($,$) is the annual mortality probability. The$ 
parameters $\theta, \rho, \alpha$ and $\gamma$ represent the "pure" rate of time preference, the intratemporal elasticity of substitution between consumption and leisure at each age $a$, the leisure preference parameter, and the intertemporal elasticity of substitution between consumption and leisure in different years, respectively.

Given the asset endowment a $(j, t, s, k)$ of the agent in year $t$, maximization of $(2)$ is subject to a lifetime budget constraint defined by the sequence:

$$
\begin{aligned}
\mathrm{a}(j+1, t+1, s, k)=[\mathrm{a}(j, t, s, k)+ & I(j, t, s, k)](1+r(t))+w(t) E(a, k)[h(a, t)-\ell(a, t, s, k)] \\
& -T(j, t, s, k)-c(j, t, s, k)-K I D(j, t, k) c_{K}(j, t, s, k), \quad(6)
\end{aligned}
$$

where $r(t)$ is the pretax return on savings and $I(j, t, s, k)$ denotes the inheritance the agent receives in year $t$. When the parents die between age 68 and 90 , their remaining assets are split between their children. Consequently, inheritances of agents who are age $j$ in year $t$ and whose parents were age $s$ at their birth are defined as follows:

$$
I(j, t, s, k)=\frac{d(j+s) \bar{A}(j+s, t, k)}{\sum_{u=23}^{45} N(j+s-u, t, u, k)} .
$$

The numerator defines the aggregate assets of income class $k$ parents who die in year $t$ at age $j+s$. The denominator defines these parents' total number of children who are between ages $j+s-45$ and $j+s-23$ in year $t$. The receipt of inheritances requires us to distinguish members of each cohort according to the ages of their parents at birth. The parents' ages at death determine when the children receive their inheritances. While the first children of parents (born when their parents were age 23) receive their inheritances between ages 45 and 67, the latest born children (born when their parents were age 45) receive their inheritances earlier in life, between ages 23 and 45 .

As in Altig, et. al. (2001) and Kotlikoff, et. al. (2001), we assume that technical progress causes the time endowment $h(\cdot)$ of each successive generation to grow at the rate $\lambda$, i.e.

$$
h(a, i)=(1+\lambda) h(a, i-1) .
$$

Gross labor income of the agent in year $t$ is derived as the product of her/his labor supply and her/his wage rate. The latter is the product of the gross wage rate $w(t)$ in period $t$ and the 
age- and class-specific earnings ability.

$$
\begin{aligned}
E(a, k)=\xi(k) e^{4.47+0.033(a-20)-0.00067(a-20)^{2}}(1+\lambda)^{a-21} & \text { with } \\
& \xi(1)=0.2, \xi(2)=1.0, \xi(3)=5.0
\end{aligned}
$$

The middle-income class profile is taken from Auerbach and Kotlikoff (1987, 52). The shift parameters $\xi(k)$ are then applied to derive income class-specific profiles. Moreover, since technological change is an important determinant of secular growth over the life cycle, we add this growth by multiplying the age-specific longitudinal earnings ability profile by the term involv$\operatorname{ing} \lambda$. Hence, the longitudinal age-wage profile is steeper the greater is the rate of technological change.

The net-taxes $T(j, t, s, k)$ of an agent in year $t$ consist of consumption, capital income, and progressive wage taxes as well as social security contributions net of pensions. Due to a contribution ceiling, pension, disability insurance and health-care contribution rates may differ across agents. Each agent's pension benefits depend on her pre-retirement earnings history, while health care and disability transfers are provided on a per capita basis to all eligible age groups.

Given individual consumption, leisure, and asset levels of all agents, we can compute the aggregate variables. For example, aggregate assets $A(t+1)$ of agents who live in period $t$ are computed from

$$
A(t+1)=\sum_{k=1}^{3} \sum_{a=21}^{90} \underbrace{\sum_{s=23}^{45} \mathrm{a}(a+1, t+1, s, k) N(a, t, s, k)}_{\bar{A}(a+1, t+1, k)}
$$

Since households die at the beginning of each period, we have to aggregate across all agents who lived in the previous period in order to compute $\bar{A}(a+1, t+1, k)$, which we need for the calculation of bequests, see (7). If we aggregate across agents who live in period $t+1$, i.e.,

$$
\mathcal{A}(t+1)=\sum_{k=1}^{3} \sum_{a=21}^{90} \sum_{s=23}^{45} \mathrm{a}(a, t+1, s, k) N(a, t+1, s, k)
$$

assets of the arriving immigrants of period $t+1$ are included. 
Finally, aggregate labor supply of agents in year $t, L(t)$, is computed from the individual labor supplies, i.e.

$$
L(t)=\sum_{k=1}^{3} \sum_{a=21}^{90} \sum_{s=23}^{45} E(a, k)[h(a, t)-\ell(a, t, s, k)] N(a, t, s, k) .
$$

\section{The Government Sector}

The consolidated government issues new debt $\Delta B(t)$ and collects net-taxes from households in order to finance general government expenditures $G(t)$ as well as interest payments on its debt.

$$
\Delta B(t)+\sum_{k=1}^{3} \sum_{a=21}^{90} \sum_{s=23}^{45} T(a, t, s, k) N(a, t, s, k)=G(t)+r(t) B(t) .
$$

With respect to public debt, we assume that the government maintains an exogenously fixed ratio of debt to output. The progressivity of the wage tax system is modelled as in Auerbach and Kotlikoff (1987). Specifically, marginal wage tax rates rise linearly with the tax base.

$P Y(t)$ defines the aggregate payroll tax base which differs from total labor earnings due to the ceiling on taxable wages. This ceiling is fixed at twice average income in the US and $\mathrm{EU}$ and at 168 percent of average income in Japan. Aggregate average social security payroll tax rates $\hat{\tau}^{p}, \hat{\tau}^{h}$ and $\hat{\tau}^{d}$ are computed each period from the relevant budget constraint for the program and region in question. For the U.S., we determine the values of three payroll tax rates for the Social Security pension system, Medicare, and the Social Security disability insurance system, i.e.

$$
\hat{\tau}^{p}(t) P Y(t)=P B(t) \quad \hat{\tau}^{h}(t) P Y(t)=H B(t) \quad \text { and } \quad \hat{\tau}^{d}(t) P Y(t)=D B(t)
$$

where $P B(t), H B(t)$ and $D B(t)$ are total outlays of the pension, health care, and disability systems, respectively. In the EU and Japan, disability insurance is part of their respective state pension systems. Hence, we do not calculate separate disability insurance payroll tax rates for those regions.

Due to the contribution ceiling, individual pension and health insurance payroll tax rates can differ from the payroll tax rate. Above the contribution ceiling, marginal social security 
contributions are zero and average social security contributions fall with the agent's income. To accommodate this non convexity of the budget constraint, we assume that the highest earnings class in each region pay pension and, in the EU and Japan, health insurance payroll taxes up to the relevant ceilings, but, at the margin, face no pension and no health care payroll taxes. The other earnings classes are assumed to face the full statutory rate on all earnings. In the U.S., the disability payroll tax is modelled in an equivalent manner. However, since there is no ceiling on U.S. Medicare taxes, all earnings groups are assumed to face the health insurance payroll tax at the margin.

If a $k$-income class agent, whose parents were $s$ years old at his birth, retires in year $z$ at the exogenously set retirement age $\bar{a}(z)$, her/his pension benefits $\operatorname{Pen}(a, i, s, k)$ in years $i \geq z$ when he is age $a \geq \bar{a}(z)$ depend linearly on her/his average earnings during his working time $\bar{W}(z, s, k)$ :

$$
\operatorname{Pen}(a, i, s, k)=\omega_{0}+\omega_{1} \times \bar{W}(z, s, k) .
$$

The region-specific parameters $\omega_{0}, \omega_{1}$ were chosen in order to approximate the replacement rates relative to individual lifetime earnings as reported in Whitehouse $(2002,55)$.

General government expenditures $G(t)$ consist of government purchases of goods and services, including educational expenditures and health outlays. Over the transition, government purchases of goods and services are held fixed per capita with an adjustment for annual technological change. Age-specific education, health, and disability outlays are also held fixed over the transition with the same adjustment for technological change. The government's budget (13) is balanced each year by adjusting the intercept on our linear formula for the average wage tax rate.

\section{The Production Side}

The economy is populated by a large number of identical firms, the sum total of which we normalize to unity. Aggregate output (net of depreciation) is produced using Cobb-Douglas production technology, i.e.

$$
F(K(t), L(t))=\phi K(t)^{\varepsilon} L(t)^{1-\varepsilon}
$$


where $K(t)$ is aggregate capital in period $t, \varepsilon$ is capital's share in production, and $\phi$ is a technology parameter. Since we posit convex capital adjustment cost, the firms' marketable output in year $t, Y(t)$, is given by the difference between gross output and adjustment costs, i.e.

$$
Y(t)=F(K(t), L(t))-0.5 \psi \Delta K(t)^{2} / K(t)
$$

where $\Delta K(t)$ measures investment in year $t$. The term $\psi$ is the adjustment cost coefficient. Larger values of $\psi$ imply greater marginal costs of new capital goods for a given rate of investment. The installation technology is linear homogeneous and shows increasing marginal cost of investment (or, symmetrically, disinvestment): faster adjustment requires a greater than proportional rise in adjustment costs.

We abstract from any taxation at the corporate level. Arbitrage between new and existing capital, therefore, implies that the latter has a price per unit of

$$
q(t+1)=1+\psi \Delta K(t) / K(t)
$$

Similarly, the arbitrage condition arising from profit maximization requires identical returns to financial and real investments.

$$
r(t) q(t)=F_{K(t)}+0.5 \psi(\Delta K(t) / K(t))^{2}+q(t+1)-q(t)
$$

The left side gives the return on a financial investment of amount $q(t)$ while the return on one unit of real capital investment is the net return to capital (which includes the marginal product of capital $F_{K(t)}$ plus the reduction in marginal adjustment costs) and capital gains.

\section{World Equilibrium}

Up to now we've described the model for the representative economy. Since we assume no migration between our three regions, the closed economy capital market equates national asset holdings from (11) to the sum of the market values of the domestic capital stock and the outstanding stock of government debt. In the open economy case, the aggregate value of world 
assets equals the market value of the world-wide capital stock plus the value of all outstanding regional government bonds:

$$
\sum_{x \in W} \mathcal{A}(t, x)=\sum_{x \in W}[q(t, x) K(t, x)+B(t, x)] \quad \text { with } \quad W=\{U S, E U, \text { Japan }\} .
$$

\section{Solving the Model}

In order to solve the model we first need to specify the preference, technology, and policy parameters. Table 1 reports our main parameter values. The preference and technology parameters are mostly taken from Kotlikoff, et. al. (2001). The reported debt levels in USA, Europe and Japan were chosen to match real interest payments reported in European Commission (2003) for the year 2000, while the retirement ages are taken from Bloendal and Scarpetta (1999) for the US and EU and from Whitehouse (2002) for Japan. The consumption tax rate for the US is taken from Kotlikoff, et. al. (2001). For the EU, the consumption tax rate is the unweighted average of the indirect tax rates in the member states, and the Japanese consumption tax rate is set at the current value of the VAT. In addition, we specify the progressive parameters of the wage tax systems in each region in order to generate realistic average and marginal tax rates (reported below), while the proportional term is computed endogenously so that the government budget is balanced by the wage tax.

In calibrating our model, we use a Japanese age-specific government health care expenditures profiles for Japan. In the case of the E.U., we use the German profile. For the US, the Medicare program applies only to households older than 65. We assume uniform Medicare expenditures by age among those over age 65 . We make the same uniform age-distribution assumption with respect to the U.S. disability system, which we assume applies to only those under age 65 .

We use the German age-specific education profile for all regions in the model and rescale it to get realistic education outlays in year 2000 in each region (see below). In addition to these parameter values, our model requires an initial distribution of assets by age and income class for each region. These profiles are region-specific. ${ }^{1}$

\footnotetext{
${ }^{1}$ Data on Japanese asset profiles were provided by Charles Horioka, while the European profiles were adjusted
} 
To run our model as an open world economy, we also need to specify how aggregate world assets are distributed across regions. These world asset shares were chosen to generate realistic current accounts vis a vis the other regions for our initial year. Finally, we have to specify the capital stocks in each region in our initial year 2000 in each region. Here we take the endogenous initial-year values that arise from a simulation without adjustment costs.

Given the initial world capital stock and asset profiles, our model applies a Gauss-Seidel algorithm to solve for the perfect foresight general equilibrium transition path of the economy. Our algorithm starts with initial guesses for the capital stocks and labor supplies in each region for the remaining years of the transition. Next we compute from equation (18) the path of region-specific market prices of capital. The path for the world interest rate after 2000 is derived from the arbitrage condition (19) for the U.S. This condition (19) is also used to update values of the existing capital stock in year 2000 in each region. Next, the wage rates are computed in each region which are equal to the respective marginal products of labor. From the capital market equilibrium condition (20) we derive aggregate initial asset holdings in year 2000, apply the region-specific saving shares and update age-specific asset holdings in 2000 in each region. Given these initial assets, the time path of tax rates (which are based on guesses in the first iteration) and factor prices, household decisions on consumption and labor supply are computed and aggregated. Then we update the path for wage tax rates, the social security payroll tax rate, and debt given the government budget constraints (13) and (14). Finally, we compute new paths for the capital stocks in each region using the capital market equilibrium condition (20) as well as (18). The new values for capital and labor are then weighted with the initial guesses of these supplies to form guesses of the time paths of these variables. The algorithm then iterates until the path of capital stock and labor converges. We give our economy 300 years to reach to a steady state. Our model in fact reaches a steady state to many decimal places prior to year 300. It also converges very tightly around the equilibrium transition path.

from German data provided by Reinhold Schnabel. US Data were derived from the 1998 Survey of Consumer Finances. 


\section{Initial Equilibrium and Baseline Path in the Case of Closed Economies}

First, our model is solved by treating every region as a closed economy. Table 2 reports the macroeconomic variables in 2000 in the three regions. Note that there is a fairly close accordance between actual and computed national income account measures of private consumption and government purchases. The one exception here is with respect to Japanese government purchases. The official data seem too high given the official reported ratio of tax revenues to national income. In our calibration, we chose to benchmark against the ratio of tax revenues to national income.

The reported shares in education, pensions and health are very close to actual levels ${ }^{2}$. The same applies to the social security payroll tax rates and the level and progressivity of the income tax in the US and EU. On the other hand, the average wage tax rate in Japan is obviously too high. Since we have assumed a fairly low consumption tax rate in Japan (see table 1), tax revenues from indirect taxes are too low in Japan ${ }^{3}$. Finally, the model's year-2000 capital-output ratios seem reasonable.

Next we turn to the baseline paths of the economies where we assume that current pension systems and other government policies are maintained. The transition paths for the three closed economies are reported in the first parts of tables 3 to 5.

The tables demonstrate that the three regions face quite different future dynamics. At the first glance, it might seem strange that the effective labor supply in all three regions is rising steadily although the economies are aging. This is mainly due to the assumed labor-augmenting technical progress. It more than offsets the future reduction in the labor force reported above (see figure 4) in the EU and Japan and substantially augments project growth in the actual number of workers in the US. Consequently, while the Japanese labor supply only increases by 76 percent over the next 100 years, the European effective labor supply more than doubles, and the US effective labor supply increases by more than a factor of five.

\footnotetext{
${ }^{2}$ See European Commission (2003), Dang et al. (2001, 26), IPSS (2003, 3) and OECD (2002, 178 and 2003).

${ }^{3}$ In future research we plan to improve this calibration.
} 
The transition paths of capital stocks also differ dramatically across the regions. The capital stock rises steadily in the US and more than doubles in the long run. But it falls in the EU and Japan. The key finding here is that capital per unit of human capital declines in all three regions; i.e., the general equilibrium dynamic transition path entails a long-run capital shortage. The reason for this crowding out of capital is the reduction in saving associated with the rise over time in taxes, particularly payroll taxes. Over the course of the century, the capital shortages lower real wages per unit of human capital by 17 percent in the U.S., by 22 percent in the E.U., and by 19 percent in Japan. This decline in real wages implies even higher payroll and wage tax rates (used to finance general government expenditures) than demographic changes, by themselves, would suggest.

The crowding out of capital also portends dramatic long-run increases in real interest rates in all three regions. This increase is greatest in Europe where interest rates rise over the century from 9.0 percent to 15.6 percent. In Japan rates rise from 9.0 percent to 12.2 percent. In addition to these increases in interest rates, there are major long-run increases in the market values of capital in all three regions. In the U.S. stock values rise over the century by 16.7 percent. The corresponding European and Japanese long-term capital gains are 15.8 percent and 11.2 percent. However, in contrast to the steady increase over time in interest rates, share valuations don't rise continuously over the transition.

Social security payroll tax rates and wage tax rates are reported in the right columns. As one would expect from the population dynamics described above (see figure 5), the largest increase in payroll tax rates in the medium run occurs in Japan where they double from 24.7 percent to 48.1 percent in the next 50 years. While the EU payroll tax rates are currently higher than in Japan, their future increase is somewhat less pronounced, and they peak at 45.5 percent. After 2050, contribution rates fall again slightly in both regions. Due to its less severe population ageing, social security payroll tax rates rise much less in the US from 13.7 percent in 2000 to 23.4 percent in 2030 and further to 25.8 percent in the long-run.

The picture is very similar in the case of wage tax rates. Due to the generous public good expenditures per capita in the EU, the average wage tax rate has to increase steadily over 
the whole transition in order to balance the budget. While the current level is 13.7 percent it almost doubles in the long run, reaching 26.8 percent. In Japan the wage tax rate rises from 14.2 percent to 23.6 percent. In the US, public expenditures per capita are lower than in Japan or the EU. Hence, the U.S. wage tax rate, which equals 10.1 percent in 2000 peaks at 16.0 percent in 2075 and falls to 15.5 percent by the end of the century.

To summarize, our closed-economy, baseline policy simulations show very severe deterioration in macroeconomic and fiscal conditions in all three regions. In the long run, the combined values of payroll and average wage tax rates exceed 40 percent in the U.S. and 60 percent in Japan and the E.U.

\section{Macroeconomic and Welfare Effects of Policy Reforms in the Closed Economies}

In this section, we consider two policy reforms. The first involves doubling immigration in every region. The second involves privatizing the pension system. We highlight the consequences of these policy reforms for the transition paths of each region's macroeconomic variables and levels of welfare.

\section{Doubling Immigration}

First we consider a doubling of immigration in each region starting in 2001 and continuing through 2050. This means that every year over the next half century the US experiences immigration of 2 million people, the EU of 900,000 people, and Japan of 108,000 people.

As tables 3 through 5 indicate, doubling immigration has non-negligible effects on macroeconomic variables and tax rates in all three regions. The increase in the effective labor supply occurs gradually. Since immigrants arrive with assets, the capital stock effects are quantitatively quite similar and, consequently, factor prices are almost constant. In the medium and long run, capital prices increase while payroll and wage tax rates fall significantly in all three regions.

However, the quantitative impact of immigration policy is quite different in the three regions. In the U.S., the effective labor supply in 2030 is [(210-185)/185] 13.5 percent larger, 
while in year 2100 it is [(686-526)/526] 30 percent larger than in the baseline path. Payroll and wage taxes, on the other hand, fall during the same years from 37.5 percent and 41.3 percent in the baseline path to 35.8 percent and 40.2 percent, respectively.

In Europe, immigration is lower than in the U.S. Consequently, doubling immigration in Europe has a smaller effect on the macroeconomy. In the years 2030 and 2100 effective labor supply only increases by 6.5 percent and 21 percent, respectively. However, Europe benefits more from immigration due to its more severe population aging. Payroll and wage taxes fall in 2030 from 59.2 percentage points to 57.5 percentage points and in 2100 from 68 percentage points to 65 percentage points.

In Japan, immigration is very modest. Doubling immigration increases the effective labor supply in 2030 only by 2.5 percent and in year 2100 only by about 10 percent. Therefore, the impact on payroll and wage taxes is also modest. In the years 2030 and 2100 they fall from 68.5 to 67.8 percentage points and from 63.8 to 62.4 percentage points, respectively. Note, however, that the long-run reduction of both taxes combined is 1.4 percentage points in Japan whereas it is more modest in the U.S. where they are reduced by 1.1 percentage points.

The welfare effects of the immigration policy are reported in Table 6 . The numbers show the change in welfare measured as a percentage of remaining lifetime resources. In all three regions the existing elderly experience small welfare gains from immigration due to the rise in capital prices. Younger and future generations are better off due to the fall in wage and payroll tax rates. Note that the welfare gains for cohorts born in 2030 are strongest in Europe, smaller in Japan and lowest in the U.S. In Europe, the very distortive tax rates are reduced in the long run by 3 percentage points. In Japan, the long run reduction is only 1.4 percentage points. In the U.S. the long run reduction is even lower, and in addition the distortions of the baseline system are much smaller compared to Europe and Japan. This explains the welfare differences between the three regions. Of course, in all three regions rich households benefit from the reform less since their income is above the contribution ceiling. 


\section{Privatizing Pensions}

Our pension privatization reform eliminates existing public pension systems at the margin, while still paying successive retires all those benefits they accrued under the existing system. This reform is modelled in the following way: Pension benefits of initial retirees are paid in full, and benefits for new retirees are phased out linearly over a 45-year period starting in 2000. Furthermore, the contribution rate to the pension system is eliminated, and transitional benefits are financed by a new consumption tax.

In the US, this additional consumption tax rate is initially 7.9 percent. It rises to a maximum value of 8.7 percent in 2020 and gradually declines thereafter. After 2071 the added tax is zero. The U.S. payroll tax rate declines immediately by 8.9 percentage points. Over the transition, the payroll tax rate rises by 2.4 percentage points since expenses for health care and disability insurance grow. In the EU, the added consumption tax rate has an initial value of 16.9 percent. It then rises to a maximum value of 18 percent in 2012 and then declines. The additional tax is zero after 2074. Because of this reform, the payroll tax is reduced by 17.2 percentage points in year 2000 and rises to a maximum of 11.4 percent in 2050. In Japan, the consumption tax rate is initially 14.2 percent. It then rises to a maximum of 18.3 percent in 2014 before declining. As in the EU, the targeted consumption tax is zero after 2074. The payroll tax, however, is 16.8 percentage points lower in 2000. And the maximum value reached is 11.8 percent in 2050 .

Of course, since part of the tax burden is shifted from payroll taxes towards consumption taxes, the burden on younger households falls and that on the elderly rises. The intergenerational redistribution associated with the consumption tax depresses aggregate consumption, which permits an increase in national saving and capital formation. The long-run consequences of this reform are dramatic in all three regions. Relative to the base case simulations, the year 2100 capital stock increases by 62.9 percent in the U.S., by 163.5 percent in the E.U., and by 149.3 percent in Japan. The higher capital stocks increase gross wages which rise until 2100 by [(94-83)/83] 13 percent in the US, by [(101-78)/78] 29 percent in Europe and [(104-81)/81] 28 percent in Japan. The combination of higher gross wages and reduced payroll and wage taxes 
boosts net wages especially in Europe and Japan. They almost triple from 0.25 [0.78(1-0.68)] to $0.75[1.01(1-0.25)]$ in Europe and from $0.30[0.81(1-0.64)]$ to 0.78 [1.04(1-0.25)] in Japan. The reductions in labor supplies in the three regions, reported in tables 3 to 5 , are a direct consequence of the positive income effects experienced by younger generations. Finally, capital accumulation drives up capital valuations in all economies and leads to lower year 2100 interest rates.

However, the advantageous macroeconomic effects of privatization come at a cost, which is shown in table 7 . The privatization reform implies a strong redistribution from older generations in all three economies towards younger and future generations. Again, the intergenerational and intragenerational redistribution is less severe in the US compared to the EU and Japan. The elderly are hurt because a large part of the financing burden of the pension system is shifted towards them via the consumption tax. However, welfare losses for the elderly in the highest income class are quite small. This is due to the fact that our policy reform leads to an enormous increase in the initial capital prices. Elderly people in the highest income class gain the most from this higher valuation so that their overall welfare losses are quite modest compared to middle-income and poor elderly. Younger and future generations benefit enormously from such a policy. In Europe and Japan, which face larger long-run financing problems, long-run welfare almost doubles compared with the base-line path.

\section{Initial Equilibrium and Baseline Path in the Case of Open Economies}

Next we turn to the case of open economies. The calibration of the simulation model is the same as for closed economies. However, we now have to give each region an initial share of total world assets. These shares, taken from the closed economy case, are 35 percent for the US, 48.4 percent for the EU, and 16.4 percent for Japan. Since in the open economy model the interest rate path is quite different, the macroeconomic structure even in the year 2000 will change. Table 8 , however, shows that the differences compared to table 2 are fairly small.

The macroeconomic structures of the open economies are almost the same as those of the closed economies. However, some differences are worth mentioning. National income is now 
lower in the EU and slightly higher in the US and Japan. Consequently, wage taxes are now higher in the EU and slightly lower in US and Japan compared to the closed economy case. In Japan, the current account shows a 3.1 percent surplus in 2000. The EU current account is in deficit, but its size - 1.2 percent of national income - is smaller than that of Japan. The U.S. current account, in contrast, shows a small year-2000 surplus. In considering these values, bear in mind that our model does not include trade with China, South East Asian, and the rest of the world outside of our three regions.

Next we compare the macroeconomic variables during the transition in the open and closed economy. In the closed economy baseline, interest rates increased the most in the EU and the least in the US (see tables 3 to 5). Consequently, in the open economy capital will predominantly flow from the US economy towards the EU. The baseline path of the open economy, therefore, shows for the US (table 9) less and for the EU (table 10) more capital accumulation than in the respective closed economy cases. Japan experiences initially capital outflows, which change to inflows in the long run. Due to these capital flows, the US and Japan experience short-run current account surpluses while the EU faces current account deficits. In the US and Japan, the wage tax rate increases are reduced slightly during the transition while they increase slightly in the EU (compared to the closed economy).

The initial current account deficit in the EU turns into a temporary surplus in the medium run. The more dramatic aging process in the EU and Japan will reverse the capital flows in the medium run so that the US will experience capital inflows. The high net foreign debt, however, prevents the current account from returning to surplus again.

Finally, the world interest rate rises until 2075 and then falls slightly thereafter. The level is somewhere in the middle of the closed economy levels for the U.S. and the E.U.

\section{Macroeconomic and Welfare Effects of Policy Reforms in the Open Economies}

Now we consider again the consequences of doubling immigration and privatizing the retirement system. 


\section{Doubling of Immigration}

The economic adjustment after a doubling of immigration is very similar to the case of the closed economies. However, due to capital flows, additional immigration now has a different impact on the world interest rate. Whereas the reduction in interest rates is weaker in Europe, it is stronger in U.S. and Japan compared to the closed economy case. As a consequence, capital income taxes fall less in Europe, progressive wage taxes increase less compared to the closed economy. Comparing tables 6 and 12 reveals that in Europe future agents in the top (low and middle) income class are better (worse) off than before. Exactly the opposite happens in the U.S and Japan.

Interestingly, the the initially elderly in the EU and Japan benefit more from the doubling of immigration in the open economy than in a closed economy. The opposite happens in the U.S. The reason is the region-specific capital price reaction after the policy reform. Whereas in the U.S. capital prices increase by 12 percent on impact, they increase in Europe only by 3 percent and in Japan they even fall slightly. In the closed economy, the domestic elderly benefit only from the increase in their domestic asset prices. In the open economy, however, the region-specific asset shares are identical across all households. Consequently, European and Japanese elderly benefit from the strong increase of U.S. assets in the same way as native U.S. savers and vice versa.

\section{Privatizing Pensions}

Next, we simulate the privatization of the existing pension systems in an open economy. Not surprisingly, the consequences are again very similar to those in the closed economy.

In the US, the consumption tax increases slightly less in the open than in the closed economy, whereas in Europe the consumption tax increases slightly more in the open economy. The reason is that privatization has a stronger positive effect on wages in the open US economy compared to the closed US economy, while the opposite applies in the EU and Japan. Finally, the drop in the interest rate due to privatization is greater in the open than in the closed US economy. In Europe and Japan exactly the opposite happens. 
The main thing to note, however, are the huge long-run welfare gains experienced by future low- and middle-income agents from the simulated privatization reform. In the EU, for example, future low-income agents experience a 90.44 percent welfare gain. In Japan and the U.S. the comparable figures are 83.51 percent and 32.95 percent, respectively.

The open economy welfare effects are quite similar to the closed economy effects, but some differences should also be mentioned. In the U.S. the elderly lose more in the closed compared to the open economy while the opposite happens in Europe and Japan. This is due to the above-mentioned changes in consumption tax rates. On the other hand, the long run intragenerational redistribution favors the European top income class in the open economy more than in the closed economy. The opposite happens in the US. Again, this is due to the long run interest rate which decreases less (more) in the open economy EU (U.S.) and consequently progressive wage taxes are lower (higher).

\section{Conclusion}

In this paper we presented a new dynamic simulation model to analyze the general equilibrium impact of ageing in the world's three major industrialized regions. Our simulation results show that ageing will greatly damage the U.S., EU, and Japanese economies by crowding out those region's capital stocks. This capital shortage lowers real wages by 19 percent and raises real interest rates by over 400 basis points.

However, ageing is not identical in all three areas considered. It is most profound in Japan and Europe and less dramatic in the US. Consequently, the macroeconomic impacts of ageing under baseline policy are quite different in the three regions. These differences in the aging process cause capital to flow from the U.S. to EU and Japan in our baseline path. Stated differently, the U.S. capital shortage is exacerbated by the need to supply capital to Japan and the European Union.

Although a doubling of immigration has some beneficial macroeconomic effects, they are extremely small. On the other hand, one can expect a significant long-run welfare improvement from eliminating current pension systems and financing accrued pension rights with an 
earmarked consumption tax. While the welfare losses of initial elderly and middle aged are modest, the welfare gains for younger and future low and middle income generations are extraordinarily large. 


\section{References}

Altig, D., A.J. Auerbach, L.J. Kotlikoff, K.A. Smetters and J. Walliser (2001): Simulating Fundamental Tax Reform in the United States, American Economic Review 91, 574-595.

Auerbach, A.J., L.J. Kotlikoff, R.P. Hagemann and G. Nicoletti (1989): The Economic Dynamics of an Ageing Population: The Case of Four OECD Countries, OECD Economic Studies 12, 97-130.

Auerbach, A.J. and L.J. Kotlikoff (1987): Dynamic Fiscal Policy, Cambridge.

Bloendal, S. and S. Scarpetta (1999): The retirement decision in OECD countries, OECD Economics Department Working Paper 202, Paris.

Boersch-Supan, A., A. Ludwig and J. Winter (2002): Ageing and International Capital Flows, in: Auerbach, A.J. and H. Herrmann (eds.), Ageing, Financial Markets and Monetary Policy, pp. 55-83.

Dang, T.T., P. Antolin and H. Oxley (2001); Fiscal Implications of Ageing: Projections of Age-related Spending, Economics Department Working Paper No. 305, OECD, Paris.

De Nardi, M., S. İmrohoroğlu and T.J. Sargent (1999): Projected U.S. Demographics and Social Security, Review of Economic Dynamics, Vol. 2 (3) pp. 575-615.

European Commission (2003): Statistical Annex to European Economy No. 4, Brussels.

Fehr, H., G. Halder, S. Jokisch and L.J. Kotlikoff (2003): A Simulation Model for the demographic transition in the OECD, Discussion Paper, University of Wuerzburg.

Gokhale, J. L.J. Kotlikoff, J. Senfton and M. Weale (2001): Simulating the Transmission of Wealth Inequality via Bequests, Journal of Public Economics 79, 93-128.

INGENUE (2002): Macroeconomic consequences of pension reforms in Europe: An investigation with the INGENUE world model, Discussion Paper, Paris.

Institute of Population and Social Security Research (IPSS) (2003): The cost of social security in Japan, Statistical Report No. 13, Tokyo.

Kotlikoff, L.J., K.A. Smetters and J. Walliser (2001): Finding a way out of America's demographic dilemma, NBER Working Paper No. 8258, Cambridge.

OECD (2002): Education at a glance, Paris.

OECD (2003): Health Data, 4th ed., Paris.

United Nations Population Division (2003): World Population Prospects: The 2002 Revision, New York.

Whitehouse, E. (2002): Pension systems in 15 countries compared: the value of entitlements, Discussion Paper 02/04, Centre for Pensions and Superannuation, Sydney. 
Figure 1: The individual life-cycle

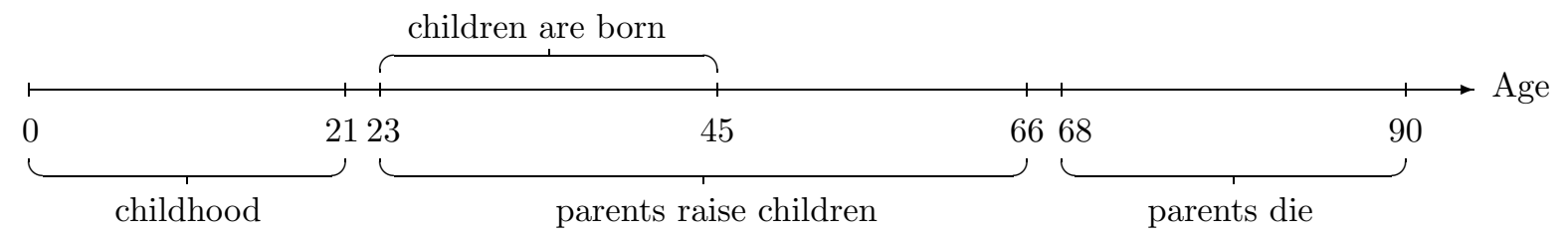

Figure 2: Life expectancy

Figure 3: Total fertility (birth per woman)
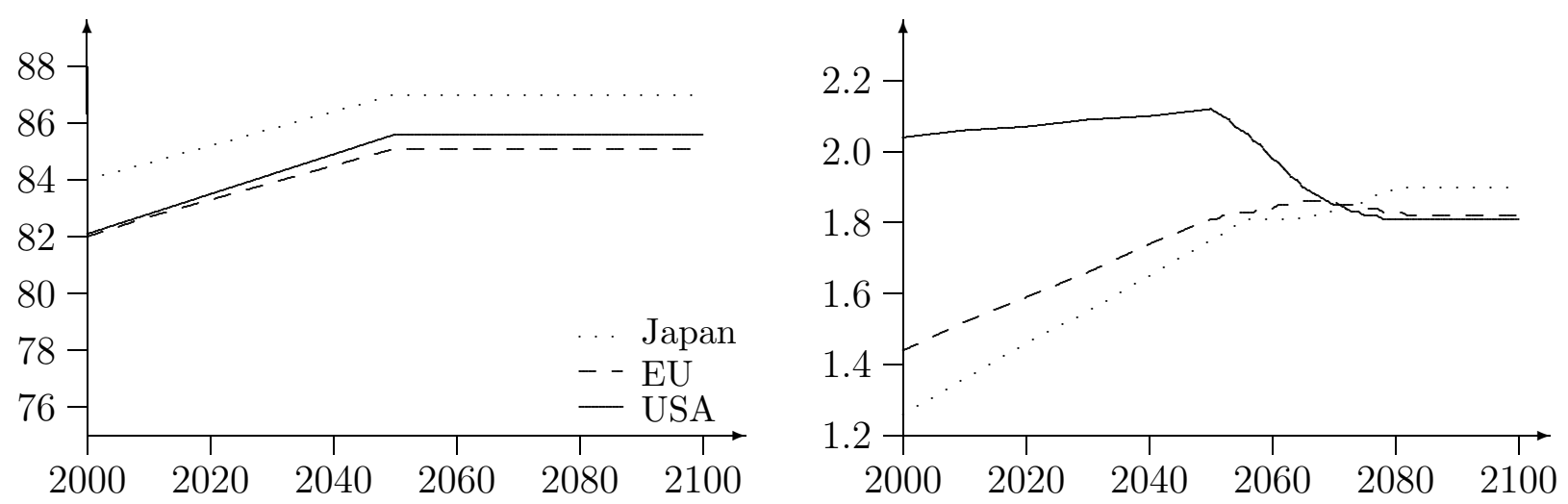
Figure 4: Total population (millions)

Figure 5: Dependency ratio (Ages 60-90/Ages 20-59)
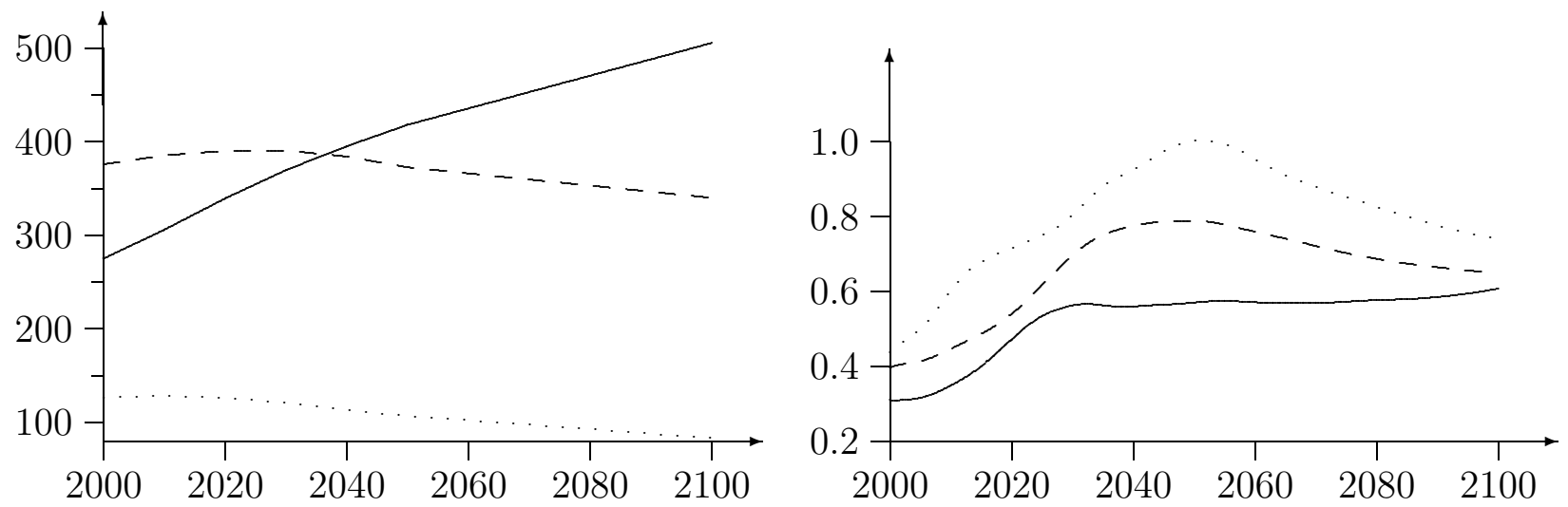

Table 1: Parameter values of the Model

\begin{tabular}{lllll}
\hline & Symbol & USA & EU & Japan \\
\hline Utility function & & & & \\
time preference rate & $\theta$ & & 0.02 & \\
intertemporal elasticity of substitution & $\gamma$ & & 0.25 & \\
intratemporal elasticity of substitution & $\rho$ & & 0.4 & \\
leisure preference parameter & $\alpha$ & & 1.5 & \\
Production function & & & & \\
technology level & $\phi$ & & 0.05461 & \\
capital share in production & $\varepsilon$ & & 10.0 & \\
adjustment cost parameter & $\psi$ & & 0.01 & \\
technical progress & $\lambda$ & & & \\
Policy parameters & & 11.3 & 19.5 & 5.0 \\
consumption tax rate (in percent) & & & 20.0 & \\
capital tax rate (in percent) & & 40 & 50 & 44 \\
debt (in percent of national income) & $B / Y$ & 63 & 60 & 60 \\
age of retirement & & & & \\
\hline
\end{tabular}


Table 2: The year 2000 of the baseline path with closed economies*

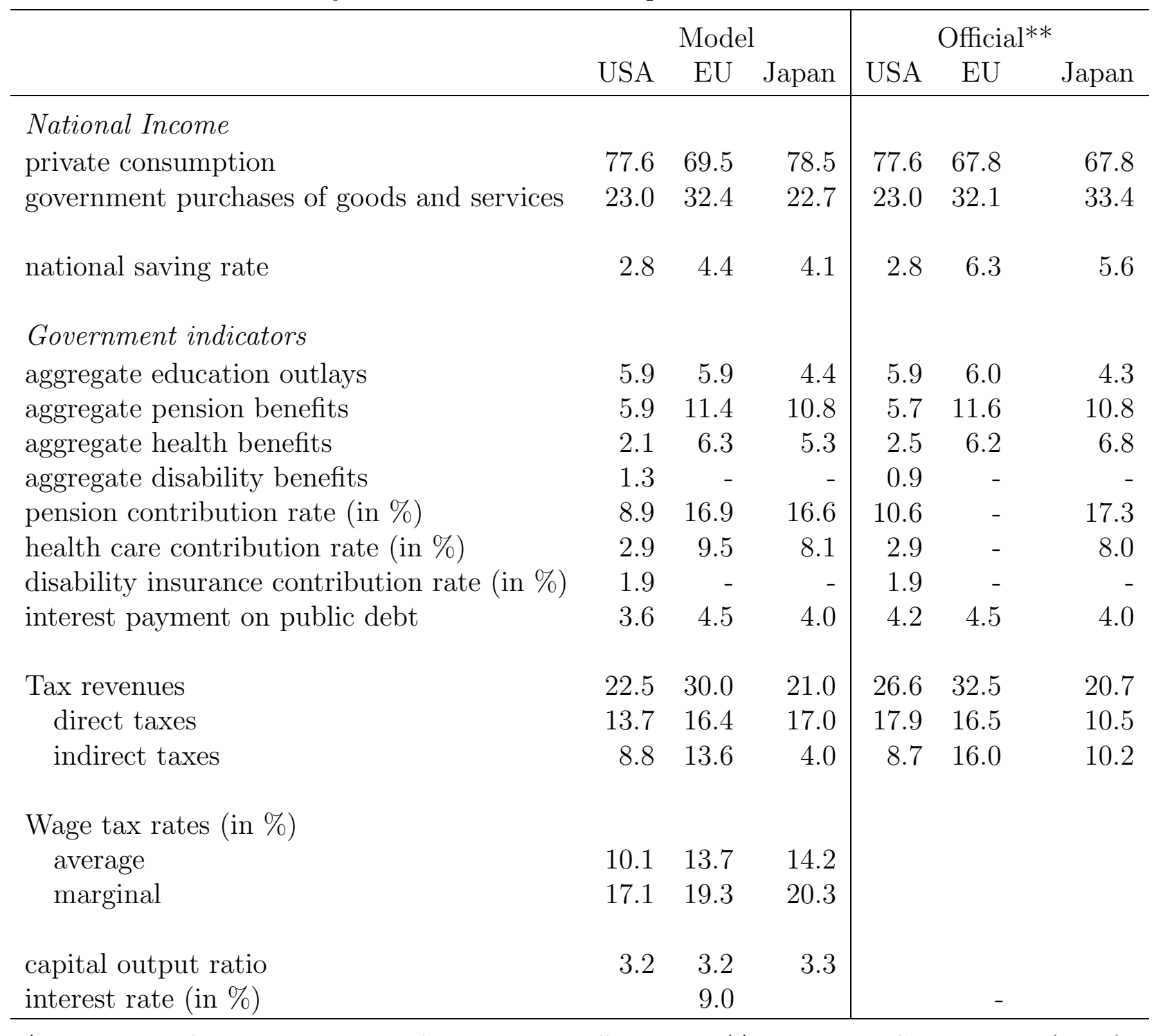

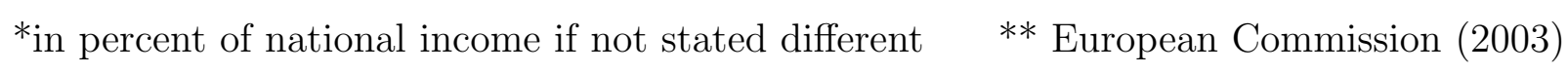


Table 3: Simulation results for the US (closed economy)

\begin{tabular}{|c|c|c|c|c|c|c|c|c|c|}
\hline & Year & $\begin{array}{l}\text { National } \\
\text { Income }\end{array}$ & $\begin{array}{l}\text { Capital } \\
\text { Stock }\end{array}$ & $\begin{array}{l}\text { Effective } \\
\text { Labor } \\
\text { Supply }\end{array}$ & $\begin{array}{l}\text { Before- } \\
\text { Tax } \\
\text { Wage }\end{array}$ & $\begin{array}{l}\text { Capital } \\
\text { Price }\end{array}$ & $\begin{array}{l}\text { Interest } \\
\text { Rate }\end{array}$ & $\begin{array}{l}\text { OASHDI } \\
\text { Cost } \\
\text { Rate }\end{array}$ & $\begin{array}{l}\text { Average } \\
\text { Wage } \\
\text { Tax }\end{array}$ \\
\hline \multirow[t]{8}{*}{ Base Case } & 2000 & 1.00 & 1.00 & 1.00 & 1.00 & 1.000 & .090 & .137 & .101 \\
\hline & 2005 & 1.10 & 1.00 & 1.13 & 0.97 & 1.048 & .092 & .137 & .106 \\
\hline & 2010 & 1.20 & 1.02 & 1.27 & 0.95 & 1.086 & .093 & .149 & .109 \\
\hline & 2020 & 1.42 & 1.10 & 1.55 & 0.92 & 1.109 & .091 & .192 & .125 \\
\hline & 2030 & 1.64 & 1.17 & 1.85 & 0.89 & 1.078 & .105 & .234 & .141 \\
\hline & 2050 & 2.18 & 1.34 & 2.59 & 0.85 & 1.125 & .118 & .239 & .159 \\
\hline & 2075 & 3.13 & 1.75 & 3.83 & 0.82 & 1.160 & .126 & .246 & .160 \\
\hline & 2100 & 4.32 & 2.45 & 5.26 & 0.83 & 1.167 & .122 & .258 & .155 \\
\hline \multirow{8}{*}{$\begin{array}{l}\text { Doubling } \\
\text { immigration }\end{array}$} & 2000 & 1.01 & 1.00 & 1.00 & 1.00 & 1.012 & .090 & .137 & .099 \\
\hline & 2005 & 1.13 & 1.01 & 1.16 & 0.97 & 1.063 & .092 & .137 & .104 \\
\hline & 2010 & 1.25 & 1.04 & 1.33 & 0.94 & 1.105 & .094 & .145 & .108 \\
\hline & 2020 & 1.53 & 1.14 & 1.69 & 0.91 & 1.136 & .093 & .183 & .125 \\
\hline & 2030 & 1.84 & 1.25 & 2.10 & 0.88 & 1.114 & .107 & .218 & .140 \\
\hline & 2050 & 2.61 & 1.55 & 3.12 & 0.84 & 1.163 & .117 & .225 & .157 \\
\hline & 2075 & 3.96 & 2.18 & 4.87 & 0.82 & 1.186 & .126 & .237 & .156 \\
\hline & 2100 & 5.65 & 3.21 & 6.86 & 0.83 & 1.184 & .119 & .254 & .148 \\
\hline \multirow{8}{*}{$\begin{array}{c}\text { Privatizing } \\
\text { pensions }\end{array}$} & 2000 & 1.01 & 1.00 & 1.01 & 1.00 & 1.051 & .090 & .048 & .098 \\
\hline & 2005 & 1.11 & 1.03 & 1.14 & 0.98 & 1.104 & .087 & .048 & .101 \\
\hline & 2010 & 1.22 & 1.08 & 1.28 & 0.96 & 1.143 & .086 & .049 & .102 \\
\hline & 2020 & 1.46 & 1.23 & 1.56 & 0.95 & 1.171 & .081 & .058 & .112 \\
\hline & 2030 & 1.72 & 1.39 & 1.85 & 0.93 & 1.153 & .087 & .068 & .120 \\
\hline & 2050 & 2.34 & 1.84 & 2.56 & 0.92 & 1.186 & .087 & .068 & .124 \\
\hline & 2075 & 3.41 & 2.68 & 3.74 & 0.92 & 1.194 & .088 & .070 & .117 \\
\hline & 2100 & 4.75 & 3.99 & 5.10 & 0.94 & 1.189 & .081 & .072 & .108 \\
\hline
\end{tabular}


Table 4: Simulation results for the EU (closed economy)

\begin{tabular}{|c|c|c|c|c|c|c|c|c|c|}
\hline & Year & $\begin{array}{l}\text { National } \\
\text { Income }\end{array}$ & $\begin{array}{l}\text { Capital } \\
\text { Stock }\end{array}$ & $\begin{array}{l}\text { Effective } \\
\text { Labor } \\
\text { Supply }\end{array}$ & $\begin{array}{l}\text { Before- } \\
\text { Tax } \\
\text { Wage }\end{array}$ & $\begin{array}{l}\text { Capital } \\
\text { Price }\end{array}$ & $\begin{array}{l}\text { Interest } \\
\text { Rate }\end{array}$ & $\begin{array}{l}\text { Social } \\
\text { Security } \\
\text { Cost Rate }\end{array}$ & $\begin{array}{l}\text { Average } \\
\text { Wage } \\
\text { Tax }\end{array}$ \\
\hline \multirow[t]{8}{*}{ Base Case } & 2000 & 1.00 & 1.00 & 1.00 & 1.00 & 1.000 & .090 & .264 & .137 \\
\hline & 2005 & 1.06 & 0.98 & 1.09 & 0.97 & 1.035 & .096 & .273 & .140 \\
\hline & 2010 & 1.12 & 0.97 & 1.18 & 0.95 & 1.066 & .096 & .288 & .143 \\
\hline & 2020 & 1.22 & 0.99 & 1.32 & 0.93 & 1.095 & .094 & .331 & .156 \\
\hline & 2030 & 1.27 & 0.99 & 1.39 & 0.92 & 1.044 & .097 & .407 & .185 \\
\hline & 2050 & 1.38 & 0.89 & 1.61 & 0.86 & 1.009 & .130 & .455 & .231 \\
\hline & 2075 & 1.62 & 0.84 & 2.02 & 0.80 & 1.087 & .153 & .430 & .262 \\
\hline & 2100 & 2.04 & 0.96 & 2.62 & 0.78 & 1.159 & .156 & .412 & .268 \\
\hline \multirow{8}{*}{$\begin{array}{l}\text { Doubling } \\
\text { immigration }\end{array}$} & 2000 & 1.00 & 1.00 & 1.00 & 1.00 & 1.002 & .090 & .264 & .137 \\
\hline & 2005 & 1.07 & 0.98 & 1.10 & 0.97 & 1.039 & .097 & .272 & .139 \\
\hline & 2010 & 1.14 & 0.97 & 1.20 & 0.95 & 1.073 & .097 & .284 & .142 \\
\hline & 2020 & 1.26 & 1.00 & 1.37 & 0.92 & 1.107 & .095 & .324 & .155 \\
\hline & 2030 & 1.34 & 1.01 & 1.48 & 0.91 & 1.060 & .100 & .391 & .184 \\
\hline & 2050 & 1.54 & 0.97 & 1.80 & 0.86 & 1.047 & .128 & .431 & .226 \\
\hline & 2075 & 1.91 & 0.98 & 2.39 & 0.80 & 1.117 & .150 & .409 & .253 \\
\hline & 2100 & 2.48 & 1.19 & 3.18 & 0.78 & 1.180 & .150 & .398 & .253 \\
\hline \multirow{8}{*}{$\begin{array}{c}\text { Privatizing } \\
\text { pensions }\end{array}$} & 2000 & 1.02 & 1.00 & 1.02 & 0.99 & 1.090 & .090 & .092 & .132 \\
\hline & 2005 & 1.09 & 1.02 & 1.11 & 0.97 & 1.135 & .087 & .093 & .131 \\
\hline & 2010 & 1.16 & 1.07 & 1.19 & 0.97 & 1.174 & .084 & .094 & .129 \\
\hline & 2020 & 1.29 & 1.20 & 1.32 & 0.97 & 1.215 & .075 & .098 & .129 \\
\hline & 2030 & 1.38 & 1.36 & 1.39 & 0.99 & 1.187 & .069 & .106 & .141 \\
\hline & 2050 & 1.56 & 1.63 & 1.55 & 1.01 & 1.157 & .069 & .114 & .149 \\
\hline & 2075 & 1.89 & 2.00 & 1.87 & 1.01 & 1.163 & .070 & .109 & .148 \\
\hline & 2100 & 2.42 & 2.53 & 2.39 & 1.01 & 1.180 & .069 & .106 & .142 \\
\hline
\end{tabular}


Table 5: Simulation results for Japan (closed economy)

\begin{tabular}{|c|c|c|c|c|c|c|c|c|c|c|}
\hline & & Year & $\begin{array}{l}\text { National } \\
\text { Income }\end{array}$ & $\begin{array}{l}\text { Capital } \\
\text { Stock }\end{array}$ & $\begin{array}{l}\text { Effective } \\
\text { Labor } \\
\text { Supply } \\
\end{array}$ & $\begin{array}{l}\text { Before- } \\
\text { Tax } \\
\text { Wage }\end{array}$ & $\begin{array}{l}\text { Capital } \\
\text { Price }\end{array}$ & $\begin{array}{l}\text { Interest } \\
\text { Rate }\end{array}$ & $\begin{array}{l}\text { Social } \\
\text { Security } \\
\text { Cost Rate }\end{array}$ & $\begin{array}{l}\text { Average } \\
\text { Wage } \\
\text { Tax }\end{array}$ \\
\hline \multirow{24}{*}{$\stackrel{\oplus}{\oplus}$} & \multirow[t]{8}{*}{ Base Case } & 2000 & 1.00 & 1.00 & 1.00 & 1.00 & 1.000 & .090 & .247 & .142 \\
\hline & & 2005 & 1.04 & 0.99 & 1.06 & 0.98 & 1.031 & .085 & .273 & .146 \\
\hline & & 2010 & 1.07 & 0.98 & 1.10 & 0.97 & 1.026 & .081 & .313 & .155 \\
\hline & & 2020 & 1.11 & 0.95 & 1.17 & 0.95 & 1.012 & .092 & .363 & .167 \\
\hline & & 2030 & 1.12 & 0.92 & 1.20 & 0.93 & 1.004 & .093 & .403 & .182 \\
\hline & & 2050 & 1.12 & 0.82 & 1.24 & 0.90 & 0.959 & .108 & .481 & .214 \\
\hline & & 2075 & 1.19 & 0.69 & 1.43 & 0.83 & 1.041 & .136 & .431 & .231 \\
\hline & & 2100 & 1.42 & 0.75 & 1.76 & 0.81 & 1.116 & .138 & .402 & .236 \\
\hline & \multirow{8}{*}{$\begin{array}{c}\text { Doubling } \\
\text { immigration }\end{array}$} & 2000 & 1.00 & 1.00 & 1.00 & 1.00 & 1.000 & .090 & .247 & .142 \\
\hline & & 2005 & 1.04 & 0.99 & 1.06 & 0.98 & 1.031 & .085 & .272 & .146 \\
\hline & & 2010 & 1.07 & 0.98 & 1.11 & 0.97 & 1.028 & .081 & .312 & .154 \\
\hline & & 2020 & 1.13 & 0.95 & 1.19 & 0.95 & 1.016 & .093 & .359 & .166 \\
\hline & & 2030 & 1.15 & 0.93 & 1.23 & 0.93 & 1.010 & .095 & .397 & .181 \\
\hline & & 2050 & 1.17 & 0.84 & 1.31 & 0.90 & 0.976 & .108 & .468 & .211 \\
\hline & & 2075 & 1.29 & 0.74 & 1.55 & 0.83 & 1.056 & .135 & .419 & .228 \\
\hline & & 2100 & 1.57 & 0.84 & 1.94 & 0.81 & 1.129 & .135 & .394 & .230 \\
\hline & \multirow{8}{*}{$\begin{array}{c}\text { Privatizing } \\
\text { pensions }\end{array}$} & 2000 & 1.01 & 1.00 & 1.02 & 1.00 & 1.087 & .090 & .079 & .135 \\
\hline & & 2005 & 1.06 & 1.03 & 1.07 & 1.00 & 1.125 & .076 & .084 & .138 \\
\hline & & 2010 & 1.09 & 1.07 & 1.10 & 1.00 & 1.128 & .071 & .089 & .142 \\
\hline & & 2020 & 1.16 & 1.16 & 1.17 & 1.00 & 1.141 & .073 & .100 & .142 \\
\hline & & 2030 & 1.22 & 1.28 & 1.20 & 1.02 & 1.152 & .064 & .105 & .145 \\
\hline & & 2050 & 1.26 & 1.49 & 1.19 & 1.06 & 1.085 & .058 & .118 & .157 \\
\hline & & 2075 & 1.38 & 1.61 & 1.31 & 1.06 & 1.097 & .063 & .108 & .154 \\
\hline & & 2100 & 1.67 & 1.87 & 1.62 & 1.04 & 1.125 & .065 & .101 & .153 \\
\hline
\end{tabular}


Table 6: Welfare effects of doubling immigration (closed economy case)

\begin{tabular}{r|rrr|rrr|rrrr}
\hline & \multicolumn{4}{|c|}{ USA } & \multicolumn{4}{c|}{ EU } & \multicolumn{4}{c}{ Japan } \\
& \multicolumn{3}{|c}{ Income class } & \multicolumn{3}{c}{ Income class } & \multicolumn{3}{c}{ Income class } \\
Birth year & 1 & 2 & 3 & 1 & 2 & 3 & 1 & 2 & 3 \\
\hline 1910 & 0.30 & 0.26 & 0.23 & 0.09 & 0.05 & 0.02 & 0.01 & 0.00 & 0.00 \\
1920 & 0.33 & 0.26 & 0.17 & 0.08 & 0.05 & 0.05 & 0.03 & 0.02 & 0.01 \\
1930 & 0.39 & 0.32 & 0.21 & 0.11 & 0.09 & 0.08 & 0.06 & 0.04 & 0.02 \\
1940 & 0.43 & 0.38 & 0.29 & 0.19 & 0.15 & 0.09 & 0.09 & 0.07 & 0.05 \\
1950 & 0.28 & 0.31 & 0.29 & 0.18 & 0.17 & 0.14 & 0.07 & 0.08 & 0.07 \\
1960 & -0.11 & 0.08 & 0.20 & 0.03 & 0.10 & 0.13 & -0.01 & 0.04 & 0.06 \\
1970 & 0.05 & 0.15 & 0.16 & 0.12 & 0.17 & 0.13 & 0.06 & 0.09 & 0.06 \\
1980 & 0.41 & 0.34 & 0.16 & 0.34 & 0.31 & 0.16 & 0.22 & 0.20 & 0.06 \\
1990 & 0.56 & 0.46 & 0.13 & 1.23 & 0.97 & 0.17 & 0.58 & 0.48 & 0.08 \\
2000 & 0.98 & 0.80 & 0.24 & 2.53 & 2.06 & 0.32 & 1.18 & 0.98 & 0.13 \\
2010 & 1.18 & 0.96 & 0.30 & 4.23 & 3.59 & 0.56 & 1.98 & 1.70 & 0.20 \\
2020 & 1.17 & 0.94 & 0.30 & 5.33 & 4.61 & 0.74 & 2.66 & 2.34 & 0.28 \\
2030 & 1.54 & 1.18 & 0.45 & 6.06 & 5.20 & 0.94 & 3.03 & 2.63 & 0.35 \\
\hline
\end{tabular}

Table 7: Welfare effects of privatizing pensions (closed economy case)

\begin{tabular}{r|rrr|rrr|rrr}
\hline & \multicolumn{3}{|c|}{ USA } & \multicolumn{4}{c|}{ EU } & \multicolumn{4}{c}{ Japan } \\
& \multicolumn{3}{|c}{ Income class } & \multicolumn{3}{c}{ Income class } & \multicolumn{3}{c}{ Income class } \\
Birth year & 1 & 2 & 3 & 1 & 2 & 3 & 1 & 2 & 3 \\
\hline 1910 & -3.86 & -2.13 & -0.59 & -7.10 & -2.90 & -0.58 & -5.70 & -1.88 & -0.28 \\
1920 & -4.12 & -2.26 & -0.65 & -9.47 & -5.55 & -2.28 & -9.22 & -5.09 & -1.61 \\
1930 & -4.71 & -2.80 & -0.94 & -10.16 & -6.30 & -2.92 & -10.32 & -5.77 & -1.85 \\
1940 & -6.60 & -3.99 & -1.49 & -10.89 & -6.76 & -2.89 & -11.50 & -7.38 & -3.31 \\
1950 & -6.28 & -3.83 & -1.72 & -8.45 & -6.01 & -3.35 & -8.98 & -6.05 & -3.28 \\
1960 & -3.11 & -2.03 & -1.67 & -2.37 & -2.13 & -3.27 & -1.46 & -1.04 & -3.11 \\
1970 & 1.09 & 0.93 & -1.04 & 4.02 & 2.62 & -2.46 & 5.02 & 3.81 & -2.41 \\
1980 & 4.40 & 3.28 & -0.18 & 11.56 & 8.58 & -0.42 & 12.06 & 9.32 & -0.81 \\
1990 & 9.60 & 6.88 & 0.91 & 23.61 & 17.10 & 1.78 & 24.00 & 18.05 & 1.10 \\
2000 & 15.95 & 11.35 & 2.48 & 42.58 & 30.60 & 4.82 & 40.65 & 29.67 & 3.54 \\
2010 & 21.58 & 15.21 & 4.04 & 64.76 & 46.52 & 8.35 & 60.22 & 43.60 & 6.22 \\
2020 & 26.01 & 18.19 & 5.33 & 82.65 & 58.96 & 11.37 & 76.79 & 55.32 & 8.51 \\
2030 & 29.37 & 20.43 & 6.31 & 94.50 & 66.88 & 13.62 & 85.03 & 60.62 & 9.95 \\
\hline
\end{tabular}


Table 8: The year 2000 of the baseline path with open economies*

\begin{tabular}{|c|c|c|c|}
\hline & USA & $\mathrm{EU}$ & Japan \\
\hline \multicolumn{4}{|l|}{ National Income } \\
\hline private consumption & 77.4 & 69.4 & 78.7 \\
\hline government purchases of goods and services & 22.8 & 32.9 & 22.4 \\
\hline current account & 0.2 & -1.2 & 3.1 \\
\hline national saving rate & 3.1 & 4.1 & 4.1 \\
\hline \multicolumn{4}{|l|}{ Government indicators } \\
\hline aggregate education outlays & 5.9 & 6.0 & 4.4 \\
\hline aggregate pension benefits & 5.9 & 11.4 & 10.8 \\
\hline aggregate health benefits & 2.1 & 6.4 & 5.2 \\
\hline aggregate disability benefits & 1.3 & - & - \\
\hline pension contribution rate (in \%) & 8.8 & 16.9 & 16.5 \\
\hline health care contribution rate (in \%) & 2.8 & 9.6 & 8.0 \\
\hline disability insurance contribution rate (in \%) & 1.9 & - & - \\
\hline interest payment on public debt & 3.6 & 4.5 & 4.0 \\
\hline Tax revenues & 22.3 & 30.3 & 20.9 \\
\hline wage tax & 7.3 & 10.5 & 10.5 \\
\hline capital tax & 6.3 & 6.3 & 6.5 \\
\hline consumption tax & 8.7 & 13.5 & 3.9 \\
\hline \multicolumn{4}{|l|}{ Wage tax rates (in \%) } \\
\hline average & 10.0 & 14.2 & 14.1 \\
\hline marginal & 17.0 & 19.7 & 20.2 \\
\hline capital output ratio & 3.2 & 3.2 & 3.3 \\
\hline interest rate (in \%) & & 9.0 & \\
\hline
\end{tabular}

* in percent of national income 
Table 9: Simulation results for the US (open economy)

\begin{tabular}{|c|c|c|c|c|c|c|c|c|c|c|}
\hline & Year & $\begin{array}{l}\text { National } \\
\text { Income }\end{array}$ & $\begin{array}{l}\text { Capital } \\
\text { Stock }\end{array}$ & $\begin{array}{l}\text { Effective } \\
\text { Labor } \\
\text { Supply }\end{array}$ & $\begin{array}{l}\text { Current } \\
\text { Account }\end{array}$ & $\begin{array}{l}\text { Before- } \\
\text { Tax } \\
\text { Wage }\end{array}$ & $\begin{array}{l}\text { Capital } \\
\text { Price }\end{array}$ & $\begin{array}{l}\text { Interest } \\
\text { Rate }\end{array}$ & $\begin{array}{l}\text { OASHDI } \\
\text { Cost } \\
\text { Rate }\end{array}$ & $\begin{array}{l}\text { Average } \\
\text { Wage } \\
\text { Tax }\end{array}$ \\
\hline \multirow[t]{8}{*}{ Base Case } & 2000 & 1.00 & 1.00 & 1.00 & .002 & 1.00 & 1.000 & .090 & .135 & .100 \\
\hline & 2005 & 1.10 & 1.00 & 1.13 & .002 & 0.97 & 1.046 & .093 & .137 & .103 \\
\hline & 2010 & 1.20 & 1.02 & 1.27 & .003 & 0.95 & 1.081 & .093 & .148 & .107 \\
\hline & 2020 & 1.42 & 1.11 & 1.55 & -.005 & 0.92 & 1.114 & .093 & .191 & .121 \\
\hline & 2030 & 1.65 & 1.19 & 1.85 & -.003 & 0.90 & 1.086 & .100 & .231 & .138 \\
\hline & 2050 & 2.18 & 1.33 & 2.58 & .024 & 0.85 & 1.082 & .122 & .238 & .156 \\
\hline & 2075 & 3.00 & 1.60 & 3.72 & .020 & 0.81 & 1.131 & .136 & .255 & .146 \\
\hline & 2100 & 4.06 & 2.14 & 5.06 & .015 & 0.81 & 1.150 & .134 & .274 & .133 \\
\hline \multirow{8}{*}{$\begin{array}{l}\text { Doubling } \\
\text { immigration }\end{array}$} & 2000 & 1.01 & 1.00 & 1.00 & .002 & 1.00 & 1.012 & .090 & .136 & .098 \\
\hline & 2005 & 1.13 & 1.01 & 1.16 & .001 & 0.97 & 1.063 & .093 & .136 & .102 \\
\hline & 2010 & 1.25 & 1.04 & 1.32 & .002 & 0.94 & 1.102 & .094 & .144 & .106 \\
\hline & 2020 & 1.53 & 1.15 & 1.68 & -.005 & 0.91 & 1.142 & .094 & .182 & .122 \\
\hline & 2030 & 1.86 & 1.28 & 2.09 & -.001 & 0.88 & 1.118 & .103 & .215 & .138 \\
\hline & 2050 & 2.61 & 1.54 & 3.11 & .021 & 0.84 & 1.124 & .121 & .224 & .154 \\
\hline & 2075 & 3.83 & 2.01 & 4.75 & .019 & 0.81 & 1.160 & .135 & .244 & .143 \\
\hline & 2100 & 5.35 & 2.85 & 6.62 & .014 & 0.81 & 1.168 & .130 & .267 & .128 \\
\hline \multirow{8}{*}{$\begin{array}{c}\text { Privatizing } \\
\text { pensions }\end{array}$} & 2000 & 1.01 & 1.00 & 1.01 & -.016 & 1.00 & 1.077 & .090 & .047 & .093 \\
\hline & 2005 & 1.12 & 1.04 & 1.14 & -.018 & 0.98 & 1.132 & .085 & .047 & .097 \\
\hline & 2010 & 1.23 & 1.11 & 1.28 & -.019 & 0.97 & 1.172 & .083 & .048 & .099 \\
\hline & 2020 & 1.48 & 1.32 & 1.56 & -.031 & 0.96 & 1.213 & .077 & .056 & .109 \\
\hline & 2030 & 1.77 & 1.57 & 1.86 & -.033 & 0.96 & 1.200 & .076 & .065 & .119 \\
\hline & 2050 & 2.46 & 2.19 & 2.60 & -.008 & 0.96 & 1.187 & .076 & .064 & .126 \\
\hline & 2075 & 3.58 & 3.18 & 3.76 & -.002 & 0.96 & 1.179 & .078 & .066 & .118 \\
\hline & 2100 & 4.93 & 4.56 & 5.11 & .002 & 0.97 & 1.167 & .075 & .070 & .108 \\
\hline
\end{tabular}


Table 10: Simulation results for the EU (open economy)

\begin{tabular}{|c|c|c|c|c|c|c|c|c|c|c|c|}
\hline & & Year & $\begin{array}{l}\text { National } \\
\text { Income }\end{array}$ & $\begin{array}{l}\text { Capital } \\
\text { Stock }\end{array}$ & $\begin{array}{l}\text { Effective } \\
\text { Labor } \\
\text { Supply }\end{array}$ & $\begin{array}{l}\text { Current } \\
\text { Account }\end{array}$ & $\begin{array}{l}\text { Before- } \\
\text { Tax } \\
\text { Wage }\end{array}$ & $\begin{array}{l}\text { Capital } \\
\text { Price }\end{array}$ & $\begin{array}{l}\text { Interest } \\
\text { Rate }\end{array}$ & $\begin{array}{l}\text { Social } \\
\text { Security } \\
\text { Cost Rate }\end{array}$ & $\begin{array}{l}\text { Average } \\
\text { Wage } \\
\text { Tax }\end{array}$ \\
\hline \multirow{24}{*}{$\infty_{\infty}^{\infty}$} & \multirow[t]{8}{*}{ Base Case } & 2000 & 1.00 & 1.00 & 1.00 & -.012 & 1.00 & 1.000 & .090 & .265 & .142 \\
\hline & & 2005 & 1.07 & 0.98 & 1.10 & -.011 & 0.97 & 1.038 & .093 & .274 & .145 \\
\hline & & 2010 & 1.13 & 0.98 & 1.19 & -.006 & 0.95 & 1.063 & .093 & .288 & .150 \\
\hline & & 2020 & 1.24 & 0.99 & 1.33 & .006 & 0.93 & 1.074 & .093 & .332 & .165 \\
\hline & & 2030 & 1.28 & 0.98 & 1.40 & -.001 & 0.92 & 1.028 & .100 & .410 & .194 \\
\hline & & 2050 & 1.41 & 0.92 & 1.63 & -.022 & 0.87 & 1.039 & .122 & .451 & .241 \\
\hline & & 2075 & 1.72 & 0.95 & 2.10 & -.024 & 0.82 & 1.119 & .136 & .412 & .279 \\
\hline & & 2100 & 2.23 & 1.18 & 2.76 & -.019 & 0.81 & 1.172 & .134 & .387 & .290 \\
\hline & \multirow{8}{*}{$\begin{array}{l}\text { Doubling } \\
\text { immigration }\end{array}$} & 2000 & 1.00 & 1.00 & 1.00 & -.012 & 1.00 & 1.003 & .090 & .266 & .140 \\
\hline & & 2005 & 1.07 & 0.98 & 1.11 & -.011 & 0.97 & 1.041 & .093 & .273 & .144 \\
\hline & & 2010 & 1.15 & 0.98 & 1.21 & -.006 & 0.95 & 1.069 & .094 & .285 & .149 \\
\hline & & 2020 & 1.28 & 1.00 & 1.39 & .005 & 0.92 & 1.085 & .094 & .325 & .164 \\
\hline & & 2030 & 1.35 & 1.01 & 1.49 & -.003 & 0.91 & 1.047 & .103 & .395 & .193 \\
\hline & & 2050 & 1.57 & 1.00 & 1.83 & -.020 & 0.86 & 1.073 & .121 & .428 & .236 \\
\hline & & 2075 & 2.02 & 1.10 & 2.48 & -.024 & 0.82 & 1.146 & .135 & .394 & .269 \\
\hline & & 2100 & 2.70 & 1.45 & 3.33 & -.019 & 0.81 & 1.192 & .130 & .378 & .274 \\
\hline & \multirow{8}{*}{$\begin{array}{c}\text { Privatizing } \\
\text { pensions }\end{array}$} & 2000 & 1.02 & 1.00 & 1.02 & -.003 & 0.99 & 1.075 & .090 & .093 & .138 \\
\hline & & 2005 & 1.09 & 1.02 & 1.12 & .000 & 0.97 & 1.118 & .085 & .094 & .138 \\
\hline & & 2010 & 1.16 & 1.06 & 1.20 & .007 & 0.97 & 1.146 & .083 & .095 & .137 \\
\hline & & 2020 & 1.28 & 1.16 & 1.33 & .021 & 0.96 & 1.165 & .077 & .100 & .138 \\
\hline & & 2030 & 1.35 & 1.26 & 1.39 & .020 & 0.97 & 1.134 & .076 & .110 & .148 \\
\hline & & 2050 & 1.52 & 1.43 & 1.55 & .009 & 0.98 & 1.126 & .076 & .119 & .154 \\
\hline & & 2075 & 1.81 & 1.70 & 1.86 & .003 & 0.97 & 1.152 & .078 & .115 & .152 \\
\hline & & 2100 & 2.33 & 2.19 & 2.40 & -.002 & 0.97 & 1.183 & .075 & .111 & .148 \\
\hline
\end{tabular}


Table 11: Simulation results for Japan (open economy)

\begin{tabular}{|c|c|c|c|c|c|c|c|c|c|c|c|}
\hline & & Year & $\begin{array}{l}\text { National } \\
\text { Income }\end{array}$ & $\begin{array}{l}\text { Capital } \\
\text { Stock }\end{array}$ & $\begin{array}{l}\text { Effective } \\
\text { Labor } \\
\text { Supply }\end{array}$ & $\begin{array}{l}\text { Current } \\
\text { Account }\end{array}$ & $\begin{array}{l}\text { Before- } \\
\text { Tax } \\
\text { Wage }\end{array}$ & $\begin{array}{l}\text { Capital } \\
\text { Price }\end{array}$ & $\begin{array}{l}\text { Interest } \\
\text { Rate }\end{array}$ & $\begin{array}{l}\text { Social } \\
\text { Security } \\
\text { Cost Rate }\end{array}$ & $\begin{array}{l}\text { Average } \\
\text { Wage } \\
\text { Tax }\end{array}$ \\
\hline \multirow{24}{*}{ vo } & \multirow[t]{8}{*}{ Base Case } & 2000 & 1.00 & 1.00 & 1.00 & .031 & 1.00 & 1.000 & .090 & .245 & .141 \\
\hline & & 2005 & 1.03 & 0.96 & 1.05 & .029 & 0.98 & 1.028 & .093 & .274 & .142 \\
\hline & & 2010 & 1.05 & 0.94 & 1.08 & .011 & 0.97 & 1.047 & .093 & .318 & .147 \\
\hline & & 2020 & 1.09 & 0.91 & 1.15 & -.004 & 0.94 & 1.064 & .093 & .369 & .160 \\
\hline & & 2030 & 1.09 & 0.86 & 1.18 & .015 & 0.92 & 1.017 & .100 & .412 & .177 \\
\hline & & 2050 & 1.05 & 0.73 & 1.19 & -.019 & 0.88 & 1.016 & .122 & .504 & .202 \\
\hline & & 2075 & 1.19 & 0.67 & 1.43 & -.008 & 0.83 & 1.116 & .136 & .430 & .226 \\
\hline & & 2100 & 1.43 & 0.77 & 1.76 & -.006 & 0.81 & 1.186 & .134 & .398 & .235 \\
\hline & \multirow{8}{*}{$\begin{array}{l}\text { Doubling } \\
\text { immigration }\end{array}$} & 2000 & 1.00 & 1.00 & 1.00 & .031 & 1.00 & 0.999 & .090 & .245 & .141 \\
\hline & & 2005 & 1.03 & 0.96 & 1.06 & .031 & 0.98 & 1.025 & .093 & .274 & .141 \\
\hline & & 2010 & 1.05 & 0.94 & 1.09 & .013 & 0.96 & 1.045 & .094 & .318 & .146 \\
\hline & & 2020 & 1.10 & 0.90 & 1.17 & -.002 & 0.94 & 1.064 & .094 & .365 & .159 \\
\hline & & 2030 & 1.11 & 0.86 & 1.21 & .014 & 0.92 & 1.023 & .103 & .406 & .176 \\
\hline & & 2050 & 1.11 & 0.75 & 1.26 & -.021 & 0.88 & 1.041 & .121 & .488 & .200 \\
\hline & & 2075 & 1.29 & 0.73 & 1.56 & -.010 & 0.83 & 1.135 & .135 & .418 & .223 \\
\hline & & 2100 & 1.60 & 0.87 & 1.96 & -.008 & 0.82 & 1.204 & .130 & .388 & .229 \\
\hline & \multirow{8}{*}{$\begin{array}{l}\text { Privatizing } \\
\text { pensions }\end{array}$} & 2000 & 1.01 & 1.00 & 1.02 & .042 & 1.00 & 1.071 & .090 & .079 & .135 \\
\hline & & 2005 & 1.04 & 1.00 & 1.07 & .040 & 0.99 & 1.106 & .085 & .084 & .134 \\
\hline & & 2010 & 1.07 & 1.01 & 1.09 & .027 & 0.99 & 1.130 & .083 & .090 & .135 \\
\hline & & 2020 & 1.13 & 1.06 & 1.15 & .019 & 0.98 & 1.156 & .077 & .103 & .138 \\
\hline & & 2030 & 1.16 & 1.10 & 1.18 & .038 & 0.99 & 1.126 & .076 & .110 & .141 \\
\hline & & 2050 & 1.16 & 1.13 & 1.16 & .001 & 1.00 & 1.117 & .076 & .127 & .144 \\
\hline & & 2075 & 1.28 & 1.22 & 1.29 & .000 & 0.99 & 1.156 & .078 & .116 & .145 \\
\hline & & 2100 & 1.57 & 1.48 & 1.60 & -.005 & 0.99 & 1.206 & .075 & .106 & .148 \\
\hline
\end{tabular}


Table 12: Welfare effects of doubling immigration (open economy case)

\begin{tabular}{r|rrr|rrr|rrrr}
\hline & \multicolumn{3}{|c|}{ USA } & \multicolumn{4}{c|}{ EU } & \multicolumn{4}{c}{ Japan } \\
& \multicolumn{3}{|c}{ Income class } & \multicolumn{3}{c}{ Income class } & \multicolumn{3}{c}{ Income class } \\
Birth year & 1 & 2 & 3 & 1 & 2 & 3 & 1 & 2 & 3 \\
\hline 1910 & 0.15 & 0.12 & 0.10 & 0.20 & 0.11 & 0.04 & 0.22 & 0.09 & 0.02 \\
1920 & 0.18 & 0.14 & 0.08 & 0.12 & 0.09 & 0.08 & 0.16 & 0.11 & 0.09 \\
1930 & 0.23 & 0.19 & 0.11 & 0.16 & 0.12 & 0.11 & 0.24 & 0.17 & 0.10 \\
1940 & 0.27 & 0.23 & 0.17 & 0.25 & 0.20 & 0.13 & 0.27 & 0.22 & 0.17 \\
1950 & 0.14 & 0.19 & 0.18 & 0.24 & 0.23 & 0.18 & 0.23 & 0.22 & 0.19 \\
1960 & -0.21 & -0.02 & 0.10 & 0.07 & 0.15 & 0.17 & 0.06 & 0.14 & 0.17 \\
1970 & 0.01 & 0.09 & 0.11 & 0.16 & 0.21 & 0.16 & 0.07 & 0.14 & 0.15 \\
1980 & 0.38 & 0.31 & 0.13 & 0.54 & 0.45 & 0.15 & 0.20 & 0.21 & 0.11 \\
1990 & 0.53 & 0.43 & 0.10 & 1.30 & 1.04 & 0.20 & 0.52 & 0.45 & 0.12 \\
2000 & 0.97 & 0.78 & 0.22 & 2.64 & 2.17 & 0.35 & 1.08 & 0.89 & 0.13 \\
2010 & 1.18 & 0.93 & 0.27 & 4.44 & 3.83 & 0.63 & 1.93 & 1.64 & 0.16 \\
2020 & 1.17 & 0.90 & 0.22 & 5.42 & 4.74 & 0.86 & 2.94 & 2.57 & 0.21 \\
2030 & 1.58 & 1.16 & 0.34 & 5.85 & 5.06 & 1.10 & 3.40 & 2.95 & 0.30 \\
\hline
\end{tabular}

Table 13: Welfare effects of privatizing pensions

(open economy case)

\begin{tabular}{r|rrr|rrr|rrr}
\hline & \multicolumn{3}{|c|}{ USA } & \multicolumn{4}{c|}{ EU } & \multicolumn{4}{c}{ Japan } \\
& \multicolumn{3}{|c}{ Income class } & \multicolumn{3}{c}{ Income class } & \multicolumn{3}{c}{ Income class } \\
Birth year & 1 & 2 & 3 & 1 & 2 & 3 & 1 & 2 & 3 \\
\hline 1910 & -3.36 & -1.65 & -0.20 & -7.58 & -3.22 & -0.69 & -6.12 & -2.08 & -0.32 \\
1920 & -3.75 & -1.95 & -0.45 & -9.72 & -5.76 & -2.46 & -9.37 & -5.18 & -1.66 \\
1930 & -4.57 & -2.69 & -0.85 & -10.32 & -6.42 & -3.05 & -10.35 & -5.72 & -1.80 \\
1940 & -6.71 & -4.11 & -1.53 & -10.91 & -6.76 & -2.93 & -11.39 & -7.18 & -3.07 \\
1950 & -6.60 & -4.15 & -1.97 & -8.50 & -5.99 & -3.30 & -8.24 & -5.54 & -2.97 \\
1960 & -3.38 & -2.39 & -2.05 & -2.40 & -2.02 & -3.10 & -0.74 & -0.57 & -2.76 \\
1970 & 1.08 & 0.70 & -1.41 & 4.19 & 2.92 & -2.19 & 5.82 & 4.30 & -2.07 \\
1980 & 4.52 & 3.16 & -0.47 & 11.89 & 9.02 & -0.12 & 12.96 & 9.79 & -0.58 \\
1990 & 10.36 & 7.07 & 0.67 & 23.87 & 17.63 & 2.14 & 25.18 & 18.74 & 1.18 \\
2000 & 17.56 & 11.95 & 2.29 & 42.93 & 31.52 & 5.47 & 40.65 & 29.61 & 3.24 \\
2010 & 23.88 & 16.07 & 3.78 & 65.26 & 48.07 & 9.42 & 60.00 & 43.65 & 5.71 \\
2020 & 28.96 & 19.32 & 4.96 & 81.46 & 59.69 & 12.84 & 77.22 & 56.39 & 8.12 \\
2030 & 32.95 & 21.87 & 5.86 & 90.44 & 65.78 & 15.39 & 83.51 & 60.58 & 9.73 \\
\hline
\end{tabular}

